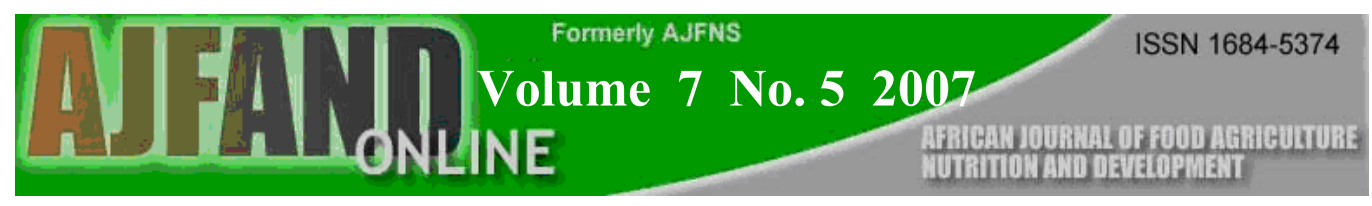

\title{
AN EVALUATION OF MILK QUALITY IN UGANDA: VALUE CHAIN ASSESSMENT AND RECOMMENDATIONS
}

By

P Grimaud ${ }^{1 *}, 2$, M L Sserunjogi ${ }^{1}$ and N Grillet ${ }^{2}$,

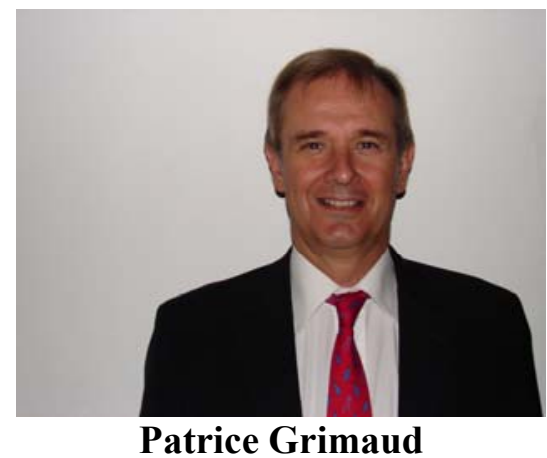

*Corresponding author Email: grimaud@,cirad.fr

${ }^{1}$ Faculty of Agriculture, Makerere University, P. O. Box 7062, Kampala, Uganda Tel: +256772 777 716; Fax: 0025641342355

${ }^{2}$ Cirad-ES, Campus de Baillarguet, F34032, Montpellier 


\section{ABSTRACT}

The sanitary quality of raw milk is an important issue in Uganda for social, economical and healthy reasons. A survey on milk quality was carried out in Mbarara major milk producing region in Uganda, between June and August 2004. The milk production system described in this paper has largely remained unchanged up to now. Milk quality was analysed at six stages of the commodity chain: farm, bicycle collector at the farm level, pick-up collecting centre, milk collecting centre, urban cooler, and vendor in Kampala city at the urban cooler level. Milk quality was evaluated using platform tests (Clot on boiling (COB), Alcohol test, milk temperature and density) and microbiological tests (total plate count, total and faecal coliforms, Escherichia coli count). Approximately half of the total coliform count was attributed to fecal coliforms including $E$. coli. This indicates great possibility of the occurrence of enteric pathogens in milk. This is partly confirmed by the large count of E. coli. The bacteria load reached very high levels close to $2 \times 10^{6}$ colony forming units per millilitre $(\mathrm{cfu} / \mathrm{mL})$ at the farm level, and these levels increased 150-fold during transportation to Kampala.

An analysis of the raw milk marketed through the informal sub sector in Uganda, revealed two main issues: (i) poor hygiene conditions from the production location all the way to the consumer; (ii) lack of an efficient preservation system to limit bacteria proliferation during transportation to Kampala. Milk was overheated at the urban informal milk heat processing units but rendered free from bacteria. However, storage of such treated milk over several days makes this process potentially more dangerous than beneficial since post processing contamination of a sterile substratum could lead to rapid proliferation of microorganisms. Milk quality across the value chain could be improved through: (i) changing milking practices to ensure better hygienic conditions; (ii) improvement of milk handling and storage conditions maintaining the cold chain. This study presents baseline information for developing a technical and scientific basis for milk quality improvement in Uganda.

Key words: Uganda, Raw Milk Value Chain

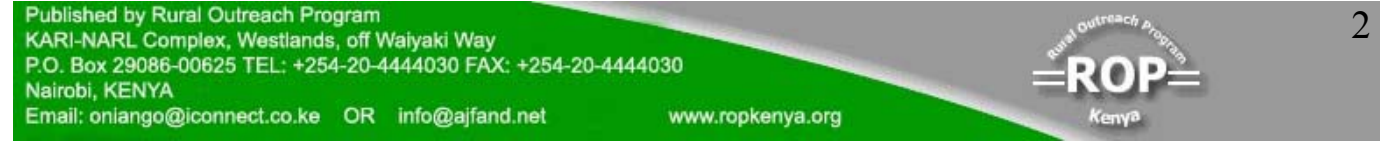




\section{INTRODUCTION}

The Ugandan economy is largely based on agriculture. Eighty percent $(80 \%)$ of the active population is involved in agriculture. Livestock farming, and more particularly dairy production, is the second major agricultural activity contributing to the national gross domestic production (GDP) after cereal products. Like in most developing countries and especially in Africa, milk consumption is increasing with the predominant market being located around urban areas where purchasing power is highest $[1,2]$. However, milk production is still largely subsistence with the attendant inefficiencies and quality problems commonly associated with such production systems. Therefore improvement of efficiency along the milk value chain, from the "Farm to Table" is an objective towards achieving economic improvement and consumer safety.

An estimated 900 million liters of milk is produced per year, of which $85 \%$ is produced from indigenous cattle, mainly Ankole breed [3, 4]. The Ankole breed, a genetic intermediate between Bos indicus and Bos taurus and related to the Sanga cattle [5], is not a dairy breed per se. They produce on average 2 Litres of milk per day and graze over a wide expanse of land often in search of fresh forage and water.

Under such circumstances, it is difficult to apply the conventional procedures for ensuring production of wholesome milk free of zoonotic and other contaminating microorganism to ensure consumer safety and provide standard raw milk for processors. Exotic cows, mainly Holstein-Friesian, were introduced for more efficient dairy production but they are still costly and more difficult to manage by the typical Ugandan farmer. Dairy production in Uganda is pasture-based and any input to improve pastures is prohibitively expensive for most farmers.

Approximately $30 \%$ of the milk produced is consumed at home. With respect to the milk that is marketed, approximately $80 \%$ is marketed through the informal market. Only a small proportion of milk is therefore currently marketed through the regulated formal market $[4,6]$. A significant part of the national milk production is provided by Mbarara area, located in South-West of Uganda and representing 5\% of the whole country with an area of $10,389 \mathrm{~km}^{2}$. Milk producers are distributed in different agroecological areas with various ways of management, from pastoral and extensive systems where local Ankole cattle are bred, to agro-pastoral and agricultural intensive zones [5]. In the intensive systems, herds often include exotic cows, with a predominance of Friesian-Holstein breed [7].

As is the case in many countries, raw milk safety is a major public health concern in Uganda. Any improvement in the quality of milk could contribute to the insurance of public health safety while at the same time having positive economic consequences.

This study was aimed at getting a better understanding of the milk value chain as well as identifying the critical points for quality insurance. Hence the study area included upstream the commodity chain in Mbarara district where the raw milk circuits have

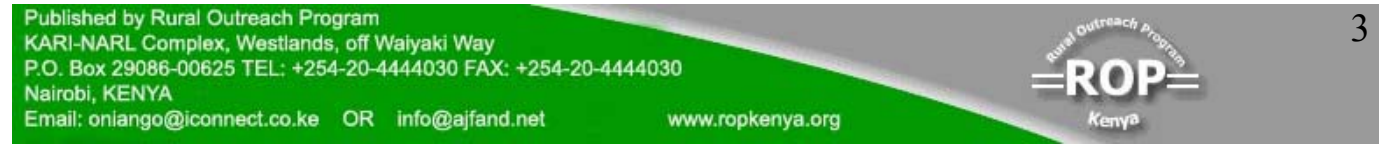




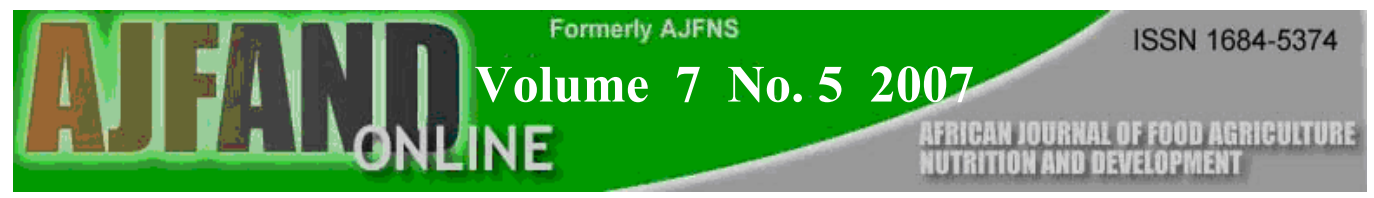

already been identified [6], and then downstream the chain after the milk has left Mbarara district to the urban markets.

\section{MATERIALS AND METHODS}

\section{Sampling procedure}

The sampling procedure was based on the schematic presentation of the raw milk commodity chain in Uganda (Figure 1). Eighty eight samples were collected from Mbarara district and Kampala City from June to August, at six different levels, namely,

(i) Fifteen farms, distributed in both the pastoral and the agro-pastoral zones of Mbarara district,

(ii) Nine bicycle collectors at the farm level;

(iii) Seven pick-up collecting centres;

(iv) Five milk collecting centres, at the rate of two samples per centre (before and after cooling);

(v) Twelve urban coolers, ten in Kampala and two in Mbarara, at the same rate of two samples per cooler; and

(vi) Fourteen vendors, distributed around Kampala, and collected while transporting the milk to their selling points. All samples were collected in sterilised containers and put in cold boxes containing ice blocks for delivery to the laboratory.

Nine samples were collected from three heat treatment units in Kampala, locally called "pasteurization units". At each unit, three samples were collected as follows: the first when milk arrived in the unit ("in"), the second just after heat treatment ("out1"), and the third when milk was sold few hours after treatment ("out2").

These last samples were neither cooled nor packed, and were transported by individual vendors who mainly sold them on their way or in their own shops. 


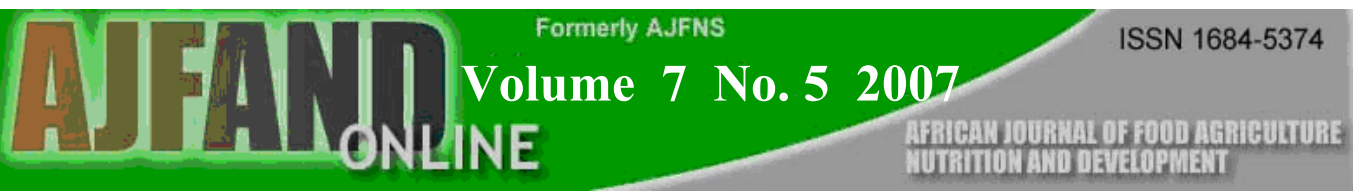

Figure 1: Different ways of raw milk handling from the cows to the consumers

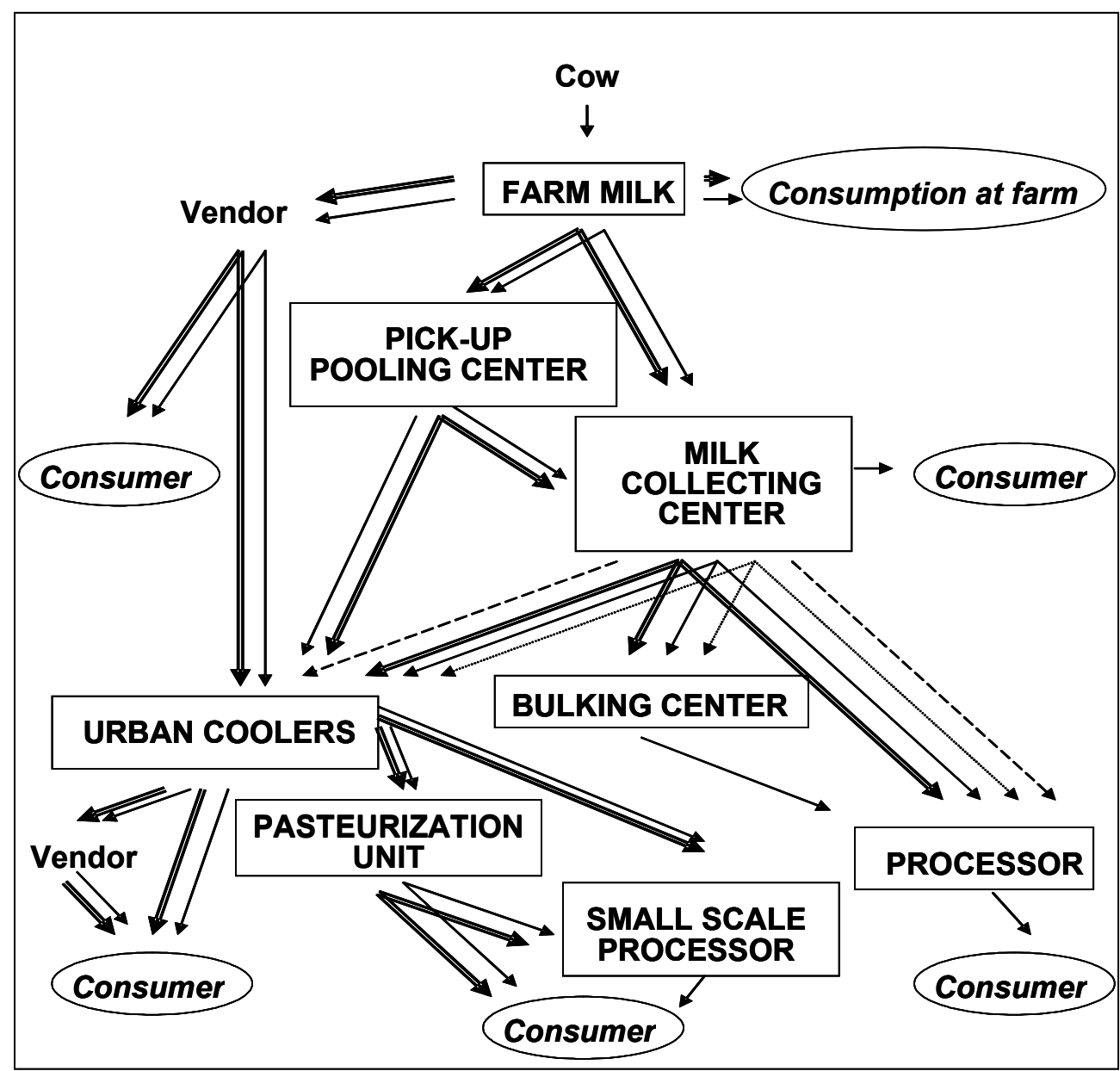

Potential circuits

Ambient temperature

Rechilled

Risk of rising temperature (depending of method of transportation $n$-tank / can) 


\section{Questionnaires}

Farmers were interviewed according to a short structured questionnaire to establish facts about farming and milk handling practices. The interview was conducted in an informal way with open questions on milk quantity, seasonal variations, milking hygiene and milk destination. The informal approach was used to make the respondents feel comfortable with the questionnaire.

\section{Milk Quality Evaluation}

Platform tests: temperature and density of raw milk were measured at the sampling points using a thermometer and a lactometer, respectively. The Alcohol test was done using a 70\% ethanol solution. Clot on boiling (COB) and Resazurin tests were done immediately after the samples were delivered to the laboratory within four hours. Samples were then frozen until further analyses. The laboratory microbial analyses were the following:

i. Total plate count (TPC): TPC was done using Plate Count Agar according to IDF standard methods [8]. Formed colonies were counted and expressed in colony forming units (cfu) per $\mathrm{mL}$.

ii. Total coliform count: Coliforms were presumptively identified in Lauryl Tryptose (LT) Broth incubated at $35^{\circ} \mathrm{C}$ for $48 \mathrm{~h}$. Positive tubes were confirmed by inoculation in Brilliant Green Bile Broth and incubated at $35^{\circ} \mathrm{C}$ for $48 \mathrm{~h}$. Results were expressed as Most Probable Number of bacterial count per $\mathrm{mL}(\mathrm{MPN} / \mathrm{mL})$ based on results of LT tubes.

iii. Faecal coliform count: Faecal coliforms were extracted from tubes positive in Lauryl Tryptose Broth, and confirmed by sub-culturing in EC Broth incubated at $45^{\circ} \mathrm{C}$ for $48 \mathrm{~h}$. Results were expressed as MPN / $\mathrm{mL}$ based on results of EC tubes.

iv. Escherichia coli count: Inoculums were made from EC broth positive tubes onto L-EMB agar and incubated $24 \mathrm{~h}$ at $35^{\circ} \mathrm{C}$.

\section{Statistical Analyses}

Data from questionnaires were analyzed using SPSS 10.

\section{RESULTS}

\section{Milk quality at the farm and final market levels}

Milk production practices influenced the level of contamination at the farm level. Some of the most important practices and the extent of their application are shown in Figure 2. Most farmers did not tie the cow's tail during milking, had no appropriate milking place, milked animals on treatment, did not wash hands before milking, did not cover the milk and had no potable (boiled) water for washing hands and utensils. Tying of the tail is important in the local setting because cows carry a lot of dust or

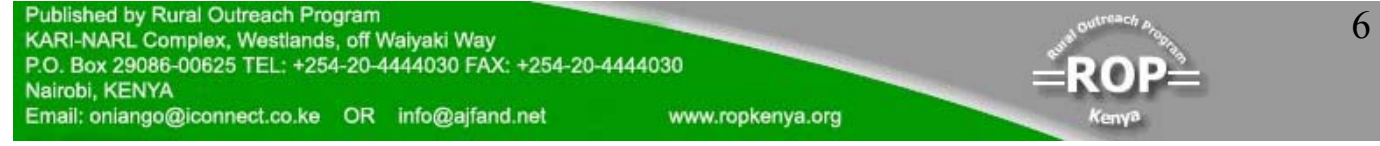


mud from the stable on their body. During milking, a lot of this dust is dislodged by the constant waving of the tail to drive way flies. This constitutes one of the most direct methods of milk contamination.

Figure 2: Most common milk handling practices by farmers

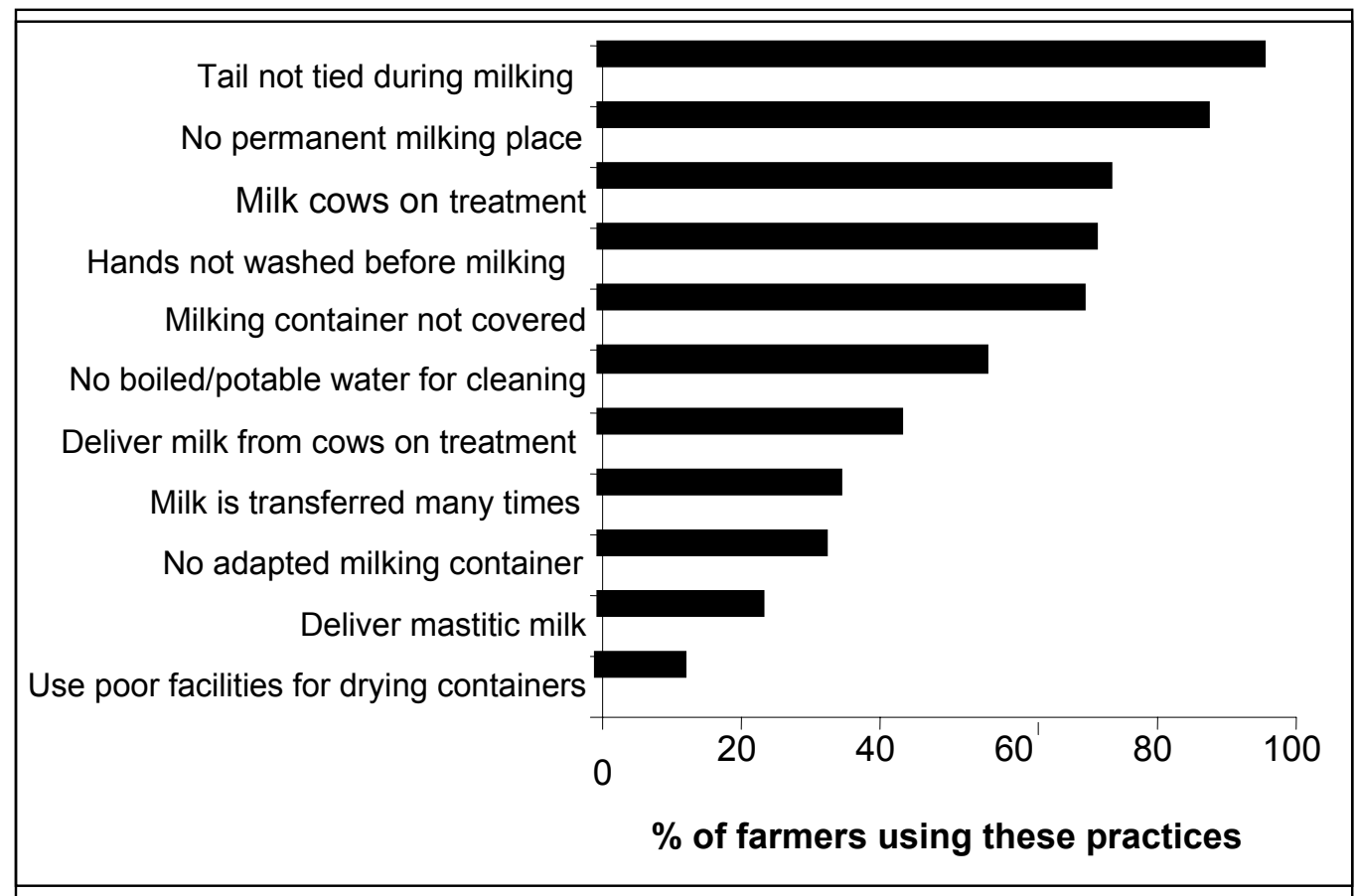

Table 1 presents milk quality parameters evaluated at the two extremes ends of the value chain, i.e., at the farm and the final marketing points. All parameters indicated a dramatic decrease in quality between the production area in Mbarara District and the urban market place. At the farm level, the total plate, total coliforms and faecal coliform counts of the milk were all below the acceptable standards. However, the average $E$. coli count was lower than the maximum acceptable level according to the IDF standards. All microbiological quality parameters indicated low milk quality in the market just before the milk is consumed. These results suggest that milk is heavily contaminated right from the farm level.

There was no significant difference in the microbiological quality of milk at farm level among the various agro-ecological zones. That is, regardless of the area the sample was collected, the microbiological quality of the milk did not differ significantly $(\mathrm{P}<0.05)$ (results not shown). However, milk from Ankole cattle in the pastoral areas had a higher density than that from Friesian-Holstein and crossbred cattle in the agro-pastoral areas (1.030-1.032 vs. 1.026-1.028, respectively, $\mathrm{P}<0.05)$. 


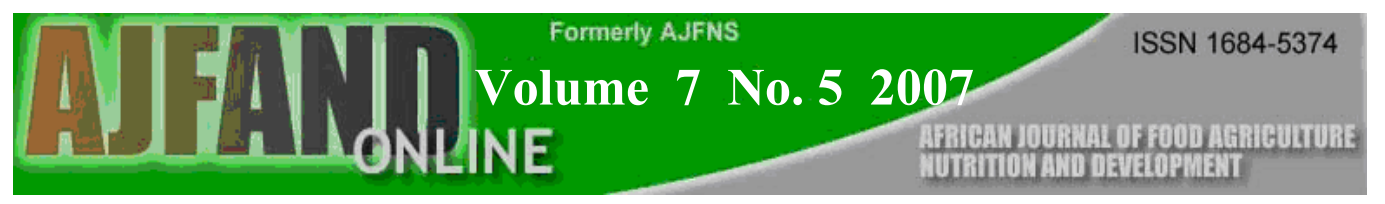

\section{Milk quality along the value chain}

Both $\mathrm{pH}$ value and density of the milk sampled from the urban market in Kampala were lower compared to values recorded for samples collected from the production areas (Figure 3). The proportion of abnormally low density milk (below 1.026) sampled from urban milk coolers and pasteurization units, which also serve as vending points, was $30-36 \%$. This proportion was even higher (up to $86 \%$ ) for milk sampled from cyclist mobile vendors. Figure 3 also presents the percentages of positive results to alcohol and $\mathrm{COB}$ tests. The worst values were recorded in samples collected in the urban market. 


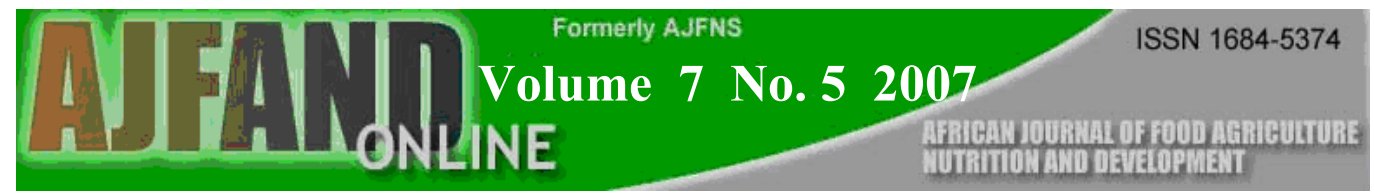

Figure 3: pH and Resazurin tests values and proportion samples which are positive to alcohol and $C O B$ tests along the value chain
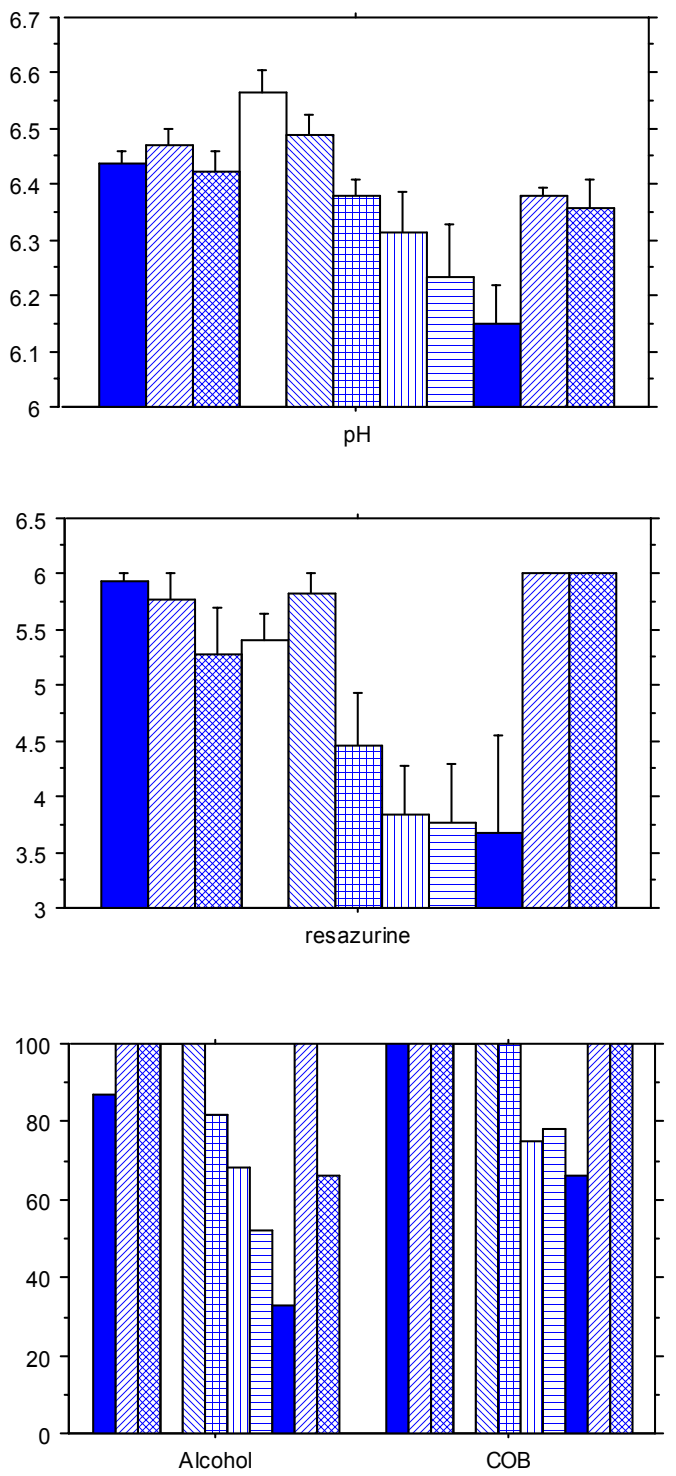

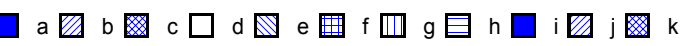

Key: a-Farm; b- bicycle collector; c-pick-up collecting centre; $d$ and e-milk collecting centre (in and out); $f$ and $f$ - urban cooler (in and out); $h$ vendor; $-i, j$ and $k$ pasteurization unit (in, out1 and out 2 )

Y-axis: 1) pH value; 2) Resazurine test grades; 3) percentage

There was a very high total plate count (TPC) at the end of the value chain which was also characterized by a high variation in the total microbial load at the different selling points in the urban market. The total microbial load increased by almost three log cycles between the farm level and the urban market (Figure 4). Total and faecal 


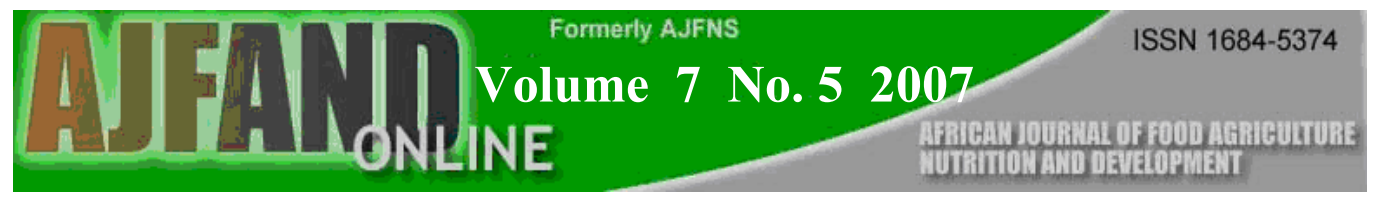

coliforms were observed in milk samples collected right at the farm level and rapidly multiplied in numbers during transit to the urban market.

Figure 4: TPC (cfu/mL), total coliforms, faecal coliforms and $E$. coli count $(\mathrm{MPN} / \mathrm{mL})$ along the value chain from production area to urban market

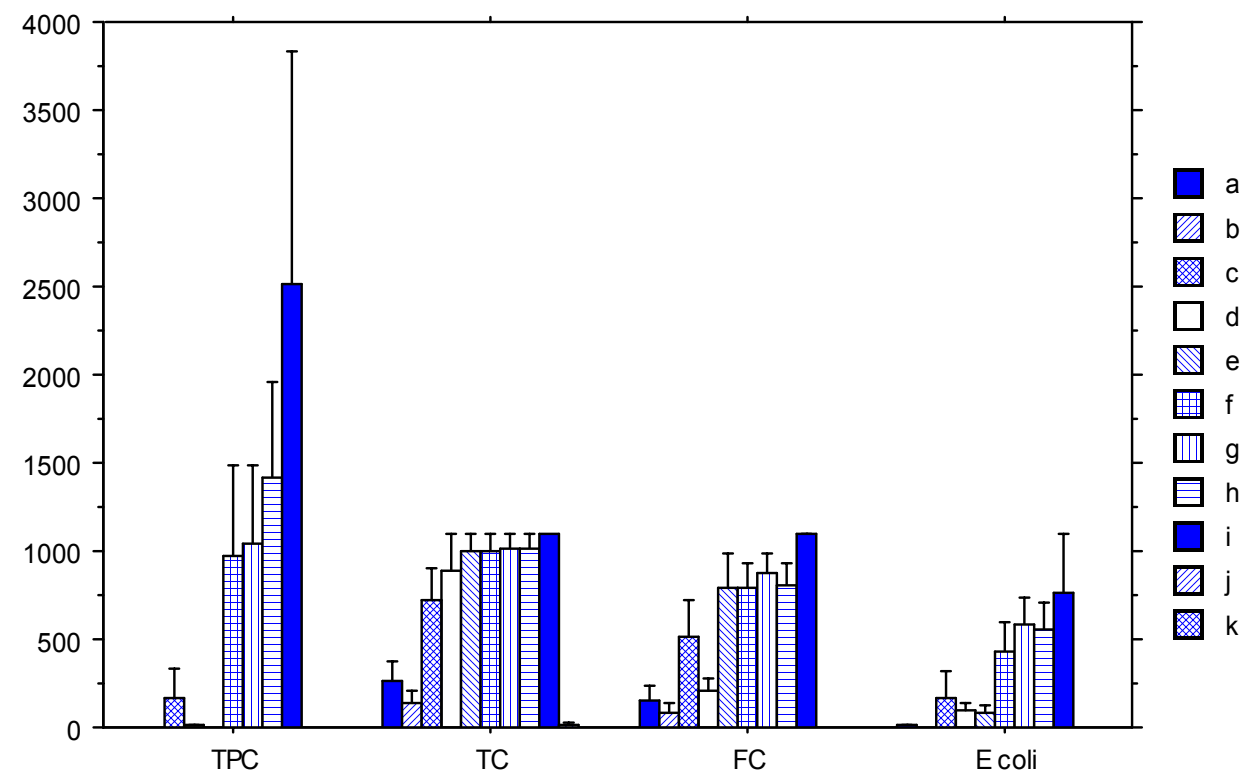

Key : a-Farm; b- bicycle collector; c-pick-up collecting centre; $d$ and e-milk collecting centre (in and out); $f$ and $g$-urban cooler (in and out); $h$-vendor; - $i, j$ and $k$ pasteurization unit (in, out1 and out2)

\section{Influence of chilling and heat treatment on milk quality}

Due to a longer storage period before transportation, chilled milk from the production area had a higher microbial load than un-chilled milk from the production area, with TPC of $4.9 \times 10^{2}$ vs. $1.4 \times 10^{7} \mathrm{cfu} / \mathrm{mL}$, respectively $(\mathrm{P}<0.05)$. However, by the time both types of milk reached the urban market, chilled milk had a lower microbial load $\left(9.3 \times 10^{2} \mathrm{cfu} / \mathrm{mL}\right)$ compared to un-chilled milk with TPC of $4.6 \times 10^{8} \mathrm{cfu} / \mathrm{mL}(\mathrm{P}<$ 0.05). Heat treatment decontaminated the milk to the extent that TPC and specific bacteria counts were $<10^{1}$ after treatment. However, unexplained rise in $\mathrm{pH}$ value, from 6.15 before heat-treatment to an average value of 6.39 , was observed. The average value was obtained from records of three pasteurization units. 


\section{DISCUSSION}

\section{Critical points of the raw milk value chain}

Following the milk value chain from the primary production region to the urban market it was possible to visualise the critical points where value is lost. The characteristic problems of the milk chain in Uganda are mainly associated with the source of the raw milk [9]. An analysis of on-farm milk production practices showed that the majority of farmers did not employ good milking practices to minimise contamination of milk on the farm. For instance, most farmers did not tie the cow's tail while milking. In addition, milk-handling equipment was not sufficiently cleaned. Lack of potable water and use of detergents was a major constrain to hygienic practices on the farm. Many farmers did not sufficiently clean the udder before milking. Yet pre-milking udder preparation plays an important role in the contamination of milk during milking [10].

Analysis and discrimination of milk based on its quality before commingling for bulk marketing is still very poor where practiced. Most of the milk is produced from indigenous cattle in relatively small quantities by many farmers. Such cattle feed over a wide expanse of land. Such circumstances make farm-level milk quality assurance very difficult. However, a few large and typical dairy farmers also contribute to the bulk milk marketed nationally. Even, though it is relatively easier to control quality at the large commercial dairy farms, if the milk produced on them is commingled with poor quality milk from the numerous small-uncontrolled producers, the resultant milk quality will be compromised. From the farm, milk is transported to milk collecting centres where it is generally chilled. From these centres, it is further transported to the major market in Kampala either in insulated trucks which allows minimal temperature increase from $4^{\circ} \mathrm{C}$ to about $10^{\circ} \mathrm{C}$, or in cans on open vehicles. The later means of transport is the second most critical point that influenced the microbiological quality of milk in this study. The two most critical points of control that have been elucidated in this study hence, are (i) at the farm level, and (ii) during the transportation of milk to the local and main urban markets particularly when the milk is un-chilled. The heavy contamination that occurs at the farm level exposes many individuals to risk as $30 \%$ of the milk is reported to be consumed at farm level in Uganda [9].

\section{The importance of temperature management on milk quality}

The comparison quality changes between chilled and unchilled milk over the value chain elucidated the importance temperature on milk quality. Since most farmers in Uganda, have no milk cooling units on the farm, the first step of cooling was at the cooling centre. The time taken to cool the milk after milking, the rate at which it is cooled and the temperature to which it is cooled will influence the rate at which multiplication will occur and hence the shelf life of the milk. These conditions will also influence the specific micro organism that will dominate in the milk. At low temperature, microbial growth and multiplication is minimal [11]. Although milk cooling allows a long storage time before delivery to the final market, the final quality will also depend on the initial contamination on the farm and during handling before

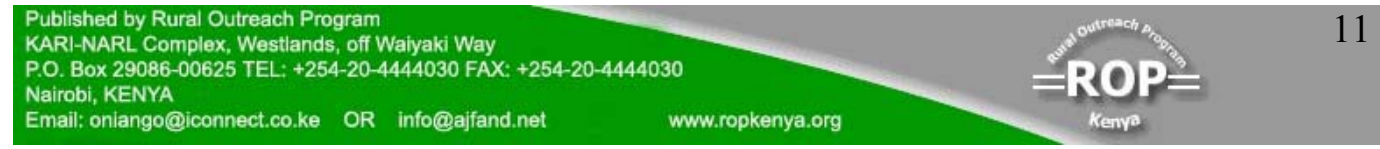


cold storage. The influence of temperature and holding time on the quality of raw milk can be demonstrated as shown in Figure 5 [12].

Figure 5: Bacterial growth in relation to milk storage temperature

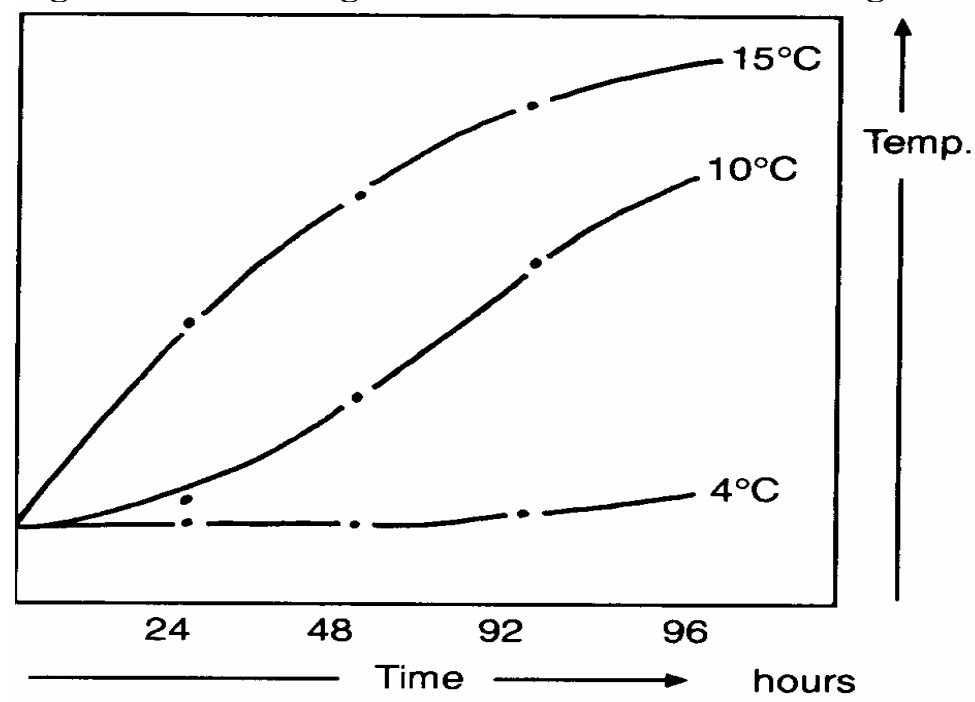

Adopted from Harding, 1985 [12]

At the end of the milk value chain, small-scale pasteurization of loose milk reduces the microbial load of raw milk to a minimum. However, there is a great danger of post-processing contamination due to the fact that the heat processed milk is not aseptically packaged. The observed increase in $\mathrm{pH}$ value and increased susceptibility of the milk to the alcohol test, imply that excessive heating of milk is applied, which causes physico-chemical changes in the milk constituents, particularly the proteins [13]. It is also believed that this alteration causes partial or total destruction of natural systems of stabilization and protection of the product, for example, the lactoperoxidase system [14]. This therefore implies that the so-heat processed milk will become an almost sterile substratum that is ideal for new colonisation by any contaminating micro organisms especially opportunistic bacteria like Listeria sp. [13]. Consequently, even if the microbial load of the heat processed milk was reduced to a minimum, several undesirable effects persist such as; (i) the treatment applied is so aggressive that the desirable compositional integrity of the milk is affected; (ii) there is a great chance of post processing contamination and hence limiting the remaining shelf life of the milk and probably consumer safety if contaminated with pathogenic microorganisms $[15,16]$. Moreover, the change in organoleptic quality of the product resulting from physico-chemical reactions (Maillard reaction) occurs [14]. These constraints partly account for the reasons why small-scale pasteurization units have not been as successful as was expected when they were introduced and supported by the Uganda Dairy Development Authority. 


\section{CONCLUSION}

The hygienic quality of milk is important for insuring consumer safety and for optimum economic value. In this study it was demonstrated that the decrease and/or loss in hygienic quality of raw milk on arrival in the urban market, in Kampala, was due to a number of factors: i) the contamination originating from the farm at the beginning of the value chain, (ii) the storage and milk handling conditions especially during transportation of milk from the primary production area to the urban market place. Accordingly, this study provided baseline information for development and implementation of HACCP system to ensure the hygienic quality of milk from the farm to the market place. The value chain forms a continuum over which value can be lost. Hence its management depends on optimum involvement of all its functional units. At the end of the chain, the conditions of storage and transportation of the retail product should ensure that quality is maintained. In this respect refrigerated storage and handling at retail points is important to complete the value chain from farm to the table. Given the fact that refrigerated storage is still a major constrain in Uganda as is the case in most tropical countries, small scale milk processing could be considered as an alternative. However, this alternative requires detailed analysis to make it feasible. The current status in Uganda showed that it is not viable at the moment.

\section{RECOMMENDATIONS}

Milk being a highly perishable commodity that deteriorates quickly under ambient temperature, cold storage is the best method for its preservation. In Uganda, the infrastructure is still insufficient, in spite of significant developments in the last few years. The road network does not allow quick transportation and there are limited cold facilities [17]. To increase efficiency along the value chain, the government of Uganda needs to establish a complete cold chain for the milk sub sector. This being a costly and lengthy undertaking, it can be implemented in logical stages. The alternative strategy of small-scale heat processing to preserve milk needs more scrutiny. Based on this study, small scale milk heat processing enterprises were not viable. They could neither ensure or guarantee consumer safety nor offer a product of acceptable sensorial quality. Moreover they were not economically viable.

The absence of quality control at every stage of the chain, and poor hygiene management at all levels contribute to the rapid deterioration of raw milk during its storage and delivery to the final consumer. The first major strategy is to put in place policies that will provide reasonable incentives to key parties involved in the value chain to significantly decrease loss of quality at the two major critical points identified in this study: (i) to increase farm-level sensitization on production of high quality milk to lower the initial microbial load of the milk, and (ii) to promote the use of milk coolers early enough after the milk has been harvested to keep low the microbial load, and use of insulated trucks to transport chilled milk so as to maintain the cold chain. Finally, a global strategy must be adopted by all stakeholders involved along the milk value chain to recognize, communicate and control quality.

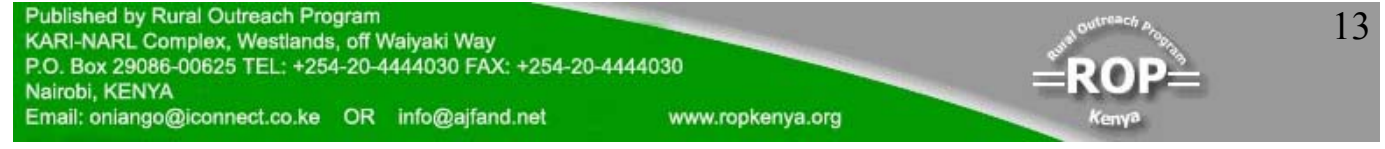




\section{Acknowledgements}

This study was supported by FSP - Fonds de Solidarité Prioritaire which is funded by the French Ministry of Foreign Affairs. The authors would further like to thank the French Embassy in Uganda and single out particularly Mrs. Michèle Baherle and Mr. Jérôme Dubois-Mercent for the special support rendered. Appreciation is also extended to the ACSS Project team, under the leadership of Mr. Alban Bellinguez. The Dairy Development Authority and its staff, particularly Mrs. Agnes Baguma is also appreciated for her assistance accorded during sampling collection. Mbarara University of Science and Technology, and especially Mr. Milson Wesuta, are appreciated for providing the laboratory and assistance for chemical analyses. Finally gratitude is extended to all the farmers and the stakeholders who helped this work.

Table 1: Some microbiological milk quality parameters at farm and market levels

\begin{tabular}{lcccc}
\hline Quality Parameter & Farm $(\mathbf{n}=\mathbf{1 5})$ & Vendor $(\mathbf{n}=\mathbf{1 6})$ & Standards $^{\text {Significance }^{1}}$ \\
\hline & 6.43 & 6.26 & $>6.40$ & $*$ \\
$\mathrm{pH}$ Value & 5.92 & 4.19 & $>4.00$ & $*$ \\
Resazurin test & 1.84 & 1417 & $<2.00$ & $* * *$ \\
Total plate count $(106 \mathrm{cfu} / \mathrm{mL})$ & 294 & 946 & $<100$ & $* *$ \\
Total coliform count $(\mathrm{MPN} / \mathrm{mL})$ & 175 & 750 & $<100$ & $* *$ \\
Fecal coliform count $(\mathrm{MPN} / \mathrm{mL})$ & 8.7 & 514.8 & $<100$ & $* * *$ \\
E. coli $(\mathrm{MPN} / \mathrm{mL})$ & & & \\
\hline
\end{tabular}

${ }^{1}$ Level of significance: $* P<.05 ; * * P<.01 ; * * * P<.001$ 


\section{REFERENCES}

1. Delgado C, Rosegrant M, Steinfeld H, Ehui S and C Courbois "Livestock to 2020", IFPRI Brief, 1999.

2. Faye B and V Alary Les enjeux des productions animales dans les pays du Sud. INRA Prod. Anim., 2001; 14: 3-13.

3. Aliguma L and JK Nyoro Regoverning markets. In: Ministry of Agriculture, Animal Industry and Fisheries (Ed). Scoping study on dairy products, fresh fruits and vegetables. Entebbe 2004.

4. Mpairwe D Undernutrition in dairy ruminants and intervention options for coping with feed scarcity in smallholder production systems in Uganda. In: Ayantunde AA., Fernández-Rivera S and G McCrabb (Eds). Coping with feed scarcity in smallholder livestock systems in developing countries. Animal Sciences Group, UR, Wageningen, The Netherlands, University of Reading, Reading, UK, Swiss Federal Institute of Technology, Zurich, Switzerland and International Livestock Research Institute, Nairobi, Kenya, 2005: 130-148.

5. Grimaud P, Mpairwe D, Chalimbaud J, Messad S and B Faye The place of Sanga cattle in dairy production in Uganda. Trop. Anim. Health Prod. 2007; 39: 217-227.

6. Grillet N, Grimaud P, Loiseau G, Wesuta M and B Faye Qualité sanitaire $\mathrm{du}$ lait cru tout au long de la filière dans le district de Mbarara et la ville de Kampala en Ouganda. Rev. Elev. Med. Vet. Trop. 2005; 4: 245-255.

7. Grimaud P, Faye B, Mugarura L, Muhoozi E and A Bellinguez Identification of research activities for the dairy sector development in Uganda: systemic and participatory approaches. Uganda J. Agric. Sci. 2004 ; 9: $879-884$.

8. IDF. International Dairy Federation, Milk collection in developing countries. Brussels, Belgium. Bulletin 281, 1987.

9. NARO. National Agricultural Research Organization, Livestock and Fisheries. In: K Mukiibi (Ed). Agriculture in Uganda. Fountain Publishers, CTA, NARO, Kampala, 2001.

10. Galton DM, Petersson LG and WG Merril Effects of premilking udder preparation practices on bacterial counts in milk and on teats. J. Dairy Sci., $1989 ; 69: 260-266$.

11. Faye B and G Loiseau Gestion de la sécurité des aliments dans les pays en développement. Sources de contamination dans les filières laitières et exemples de démarches qualité. In: Actes de l'atelier international CIRAD FAO. Montpellier, 2002: 11-13.

12. Harding F Milk quality. Blackie Academic and Professional, Glasgow. 1985. 


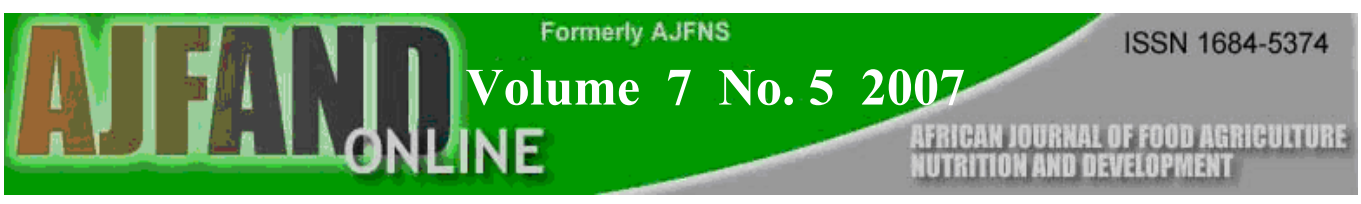

13. Asperger H Microbiology of pasteurized milk. Bull. Int. Dairy Fed., 1993; 281: $14-16$.

14. Montel MC, Beuvier E and A Hauwuy Pratiques d'élevage, microflore du lait et qualités des produits laitiers. INRA Prod. Anim., 2003; 16 : 279-282.

15. Asperger H Methods for recontamination control. Bull. Int. Dairy Fed., 1993; 281: 16 -19.

16. Meyer $\mathbf{C}$ and JP Denis Elevage de la vache laitière en zone tropicale. CiradEmvt, Montpellier, 1999.

17. Isharaza WK Approaches to quality control of milk and dairy products in Uganda. In: Atelier sur la qualité des produits animaux dans les pays tropicaux, CIRAD, Montpellier, $2002: 83-85$. 